Tatiana A. Senina (nun Kassia)

Saint Petersburg State University of Aerospace Instrumentation

Saint Petersburg, Russia

mon.kassia@gmail.com

\title{
CONCERNING THE DATES OF ST. MAKARIOS OF PELEKETE'S LIFE AND THE DATING OF HIS VITA
}

The Vita of St. Makarios of Pelekete, ${ }^{1}$ one of the members of the Orthodox resistance in the second period of Byzantine Iconoclasm, does not contain the exact dates of his birth or death. In the Dumbarton Oaks Hagiography Database, ${ }^{2}$ the years of Makarios's life are defined as $760-840$, but there are no sufficient grounds for such a precise dating in the sources.

The attempts to move the date of Makarios' birth to $752^{3}$ is based on an unfortunate misprint in the publication of the Greek text of the Vita: the passage of the Vita concerning the ordination of the saint by

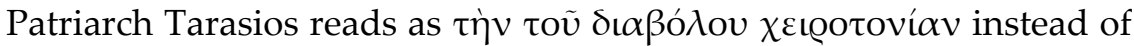

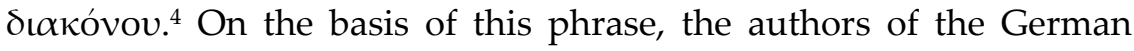
Prosopography built a whole theory, according to which Makarios entered a monastery and even managed to become an abbot there and get ordained before 787, thus instead of "diabolical ordination" that he had received from the iconoclasts, Patriarch Tarasios gave him the Orthodox ordination - hence, the birth date of the saint should be pushed back to the 750s. However, this is based on a mis-

(1) See the literature on Makarios in Prosopographie der Mittelbyzantinischen Zeit, Abt. I.: (641-867), hg. R.-J. LILIE, C. LUDWIG, Th. PRATSCH und I. RocHOW, Berlin, 1998, \# 4672. His Vita (BHG 1003) is published in J. VAN DEN GHEYN, "S. Macarii monasterii Pelecetes hegumeni Acta Graeca," $A B, 16$ (1897), pp. 140-163; below MAG. I have prepared the commented Russian translation of the Vita which will be published in the book Жития византийских святых эпохи иконоборчества, т. 1 (Byzantina), Санкт-Петербург, forthcoming.

(2) <http://128.103.33.14/saints2/dohp.asp?cmd=SShow\&key=18>, accessed on $01 / 17 / 2014$.

(3) Prosopographie der Mittelbyzantinischen Zeit, pp. 120-121.

(4) MAG, p. 149.15. 
understanding: already Ch. Van de Vorst noticed this error and

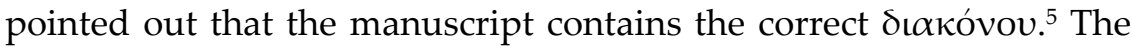
authors of the Prosopography disagreed with Ch. Van de Vorst assuming that he had in mind the text of the Vita, published in the Analecta Bollandiana when he spoke about the manuscript, but the phrase: “Dans le texte s'est glissée une faute d'impression assez décon-

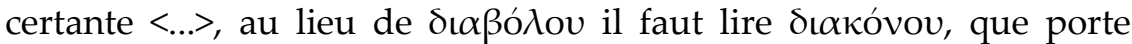
d'ailleurs le manuscrit," does not make such an interpretation possible: the word "que porte d'ailleurs le manuscrit" undoubtedly refer

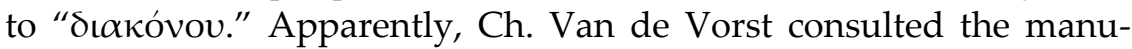
script, according to which the Vita was published. Moreover, the Iconophiles at the Second Council of Nicaea even recognized the ordinations of the Iconoclastic bishops of the first period, not to mention the clergy, thus even if Makarios was ordained by the heretics, the Patriarch would not re-ordain him.

According to the Vita, having become the leader of the Pelekete's monastery, Makarios began to perform miraculous healings. Gradually the rumors about him reached the Patriarch. Tarasios summoned him and ordained deacon; immediately after deacon's ordination Makarios was ordained priest. ${ }^{6}$ It is difficult to say exactly in which part of Tarasios' Patriarchal tenure (784-806) this happened, but Makarios had to be at least thirty years of age, ${ }^{7}$ and given the fact that he had already been an abbot for some time, he rather had to be about forty years old. If so, the date of Makarios' birth had to be no later than 766. Apparently Makarios was the same age or slightly older than St. Theodore the Studite. ${ }^{8}$ Thus, the date of Makarios' birth can tentatively be considered to happen in late 750 s.

(5) Ch. VAn DE Vorst, "Note sur S. Macaire de Pélécète," AB, 32 (1913), p. 270 , n. 1 .

(6) As may be understood from $M A G$, p. 149.17-18.

(7) This was the minimum age for being ordained a priest according to the canon law (14th canon of the Sixth Ecumenical Council).

(8) C. Mango and I. Ševčenko suggested that Makarios was significantly older than Theodore, since Theodore in his letters addressed Makarios with great respect and called Makarios his father and himself the son (five letters of Theodore to Makarios have survived from the period of the second Iconoclasm) (C. MANGO and I. ŠEVČENKO, "Some Churches and Monasteries on the Southern Shore of the Sea of Marmara," DOP, 27 (1973), p. 245). However, it should be noted that such addressing may not be the indication of age but rather of great respect to the addressee. Thus, from one letter of Theodore to 
Makarios died in the reign of Emperor Theophilos. According to the Vita, after the persecution of Iconophiles was resumed under this Emperor, the saint was summoned to Constantinople, and was interrogated by the Eparch who in vain was forcing Makarios to renounce icon veneration. Having ordered to scourge the abbot, the Eparch threw him into the city prison. ${ }^{9}$ Given the fact that the persecution began not at the very beginning of Theophilos' reign, but only in the spring of $833,{ }^{10}$ we may assume that it was the time when Makarios was imprisoned. In prison the saint performed several miracles. This irritated the Eparch, and Makarios was exiled away from the city to the island of Aphusia (now Avşa) at the other end of the Sea of Marmara. In exile, however, the saint enjoyed the unrestrained life and complete freedom: he worked miracles, built a church, founded a monastery, ${ }^{11}$ and until his death was held in high esteem among the local dwellers. ${ }^{12}$ The Vita ends with a description of miraculous healings which happened at the tomb of the saint. Thus, the death of Makarios can tentatively be dated to the time after 835 .

When was the Vita written? I. Ševčenko claims that its author "neglects to tell us where he succeeded to Makarios, whether he was his direct or indirect successor, and exactly when and where Makarios died,"13 and apparently is inclined to believe that the Vita was written much later than the events it described, since, in Ševčenko's opinion, the hagiographer's use of the nickname "Jannes" for Patriarch John

Patriarch Nicephorus we learn, that the Patriarch called himself the "son" of the abbot, even though he had a patriarchal rank and was of the same age as Theodore (in fact, Nicephorus was one year older); see Theodori Studitae Epistulae, rec. G. FATOUROS (CFHB, 31), New York, 1992, vol. II, Ep. 423.12.

(9) $M A G, \S 13$.

(10) See the review of the sources in W. TREADGOLD, The Byzantine Revival, 780-842, Stanford, 1988, p. 436, n. 386.

(11) From the Vita it is not clear what kind of monks gathered in this monastery - the same monks who lived with Makarios in the monastery he had founded on the shore of Bosphorus in the reign of Michael II (MAG, $\S 12)$, or this was an entirely new monastic community.

(12) See $M A G$, § 15-16.

(13) I. ŠEVČENKO, "Hagiography of the Iconoclast Period," in: Iconoclasm. Papers given at the Ninth Spring Symposium of Byzantine Studies. University of Birmingham. March 1975, eds. A. BRYER and J. HERRIN, Birmingham, 1977, p. 117. 
the Grammarian "is a form preferred by later texts." ${ }^{14}$ Yet, this is not the case. The earliest uses of this nickname in the sources date back to the beginning of the second Iconoclasm. Thus, Theodore the Studite calls John the Grammarian "the new Jannes" in one of his letters to Naukratios from $816 .{ }^{15}$ It is possible that this nickname for the main ideologist of the Iconoclasts, "of corrupt mind, reprobate concerning the faith," like the ancient sorcerers, the opponents of Moses (2 Tim 3:8), came from the Patriarch Nicephorus who compared the leaders of the Iconoclasts with sorcerers Jannes and Jambres in his Apologeticus Maior, "These are new Jannes and Jambres, the images of that wicked pair,"16 apparently, having in mind Antony, Bishop of Sylaeum and John the Grammarrian who headed the group of which collected testimonies against icon veneration from June to December of 814. In this way "Jannes" became the nickname of John in the Iconophile milieu from the beginning of the second Iconoclasm.

It seems quite clear from the text of the Vita that Makarios died in exile on Aphusia, surrounded by his monks, and was buried in the monastery he had founded. The author of the Vita, monk Sabas, reported that he was an eyewitness to the life of Makarios and became his successor as the head of the monastery. ${ }^{17}$ Obviously, Sabas was the abbot in the monastery on Aphusia, and not in the Pelekete monastery because after the exile of Makarios under Leo V the Pelekete monastery was headed by other abbots: first, by a certain unnamed abbot, and then after 823 by Abbot Sergios, an addressee of the correspondence of Theodore the Studite. ${ }^{18}$ Both successors of Makarios on the hegumen's position, according to the reconstruction of Ch. Van de Vorst, were not too steadfast in confessing the Orthodoxy. ${ }^{19}$ Indeed, judging by the letter of Theodore to Sergios, even though he

(14) ŠEVČENKO, "Hagiography of the Iconoclast Period," n. 31.

(15) See Theodori Studitae Epistulae, rec. FATOUROS, vol. II, Ep. 151.45.

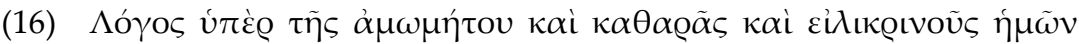

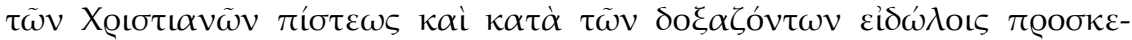

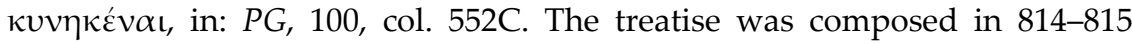
(P. J. AleXANDER, The Patriarch Nicephorus of Constantinople: Ecclesiastical Policy and Image Worship in the Byzantine Empire, Oxford, 1958, p. 182).

(17) $M A G, \S 23$.

(18) Theodore also wrote to the Pelekete's monks concerning the election of a new abbot; see Theodori Studitae epistulae, rec. FATOUROS, vol. II, Ер. 501 и 512.

(19) See VAN DE VORST, “Note sur S. Macaire,” pp. 271-273. 
and the previous abbot did not join the Iconoclasts, they did not openly speak for icon veneration either, fearing that their monastery might be dispersed. If the Pelekete monks adhered to the position of "silent" icon veneration during the persecutions, this may explain the reluctance of Makarios to return to the monastery after the death of Emperor Leo V. ${ }^{20}$

What position concerning icon veneration was advocated by Sabas who became the leader of the monastery on Aphusia after the death of Makarios? When the hagiographer began to tell the story of the reign of Leo V the Armenian, he made a reservation that "we, inferior to the present time, would give place to another person" to speak about the atrocities of $\mathrm{Leo}^{21}$ - and this is possibly an allusion to insufficiently bold behavior of the Aphusian monks in the time of the persecution - it is likely that they, too, were the supporters of the "silent" icon veneration. An indirect confirmation is the fact that John the Grammarian is introduced in the hagiographic narrative as "someone who is another Jannes," 22 and the murder of Leo the Armenian is described in remarkably scanty words in almost inaudible manner, "And behold, when the saint thus endured the sufferings in exile, the retribution approached the unfair one: he received the deserved punishment in those places where he did the iniquities." 23

A little below Sabas again mentioned Leo the Armenian and his two successors on the throne - and it is the only place in the Vita, which referred to Michael II and Theophilos, "Thus, when the tyrant was taken away and the one reigning after him was destroyed in the same way, this one inherits not lesser impiety from them, or, better to say, the kingdom, and these horrors are not condemned to oblivion with time." 24

(20) Judging by his correspondence with Theodore the Studite, Makarios upheld the same strict position as Theodore who did not approve returning to the monasteries until the complete restoration of Orthodoxy.

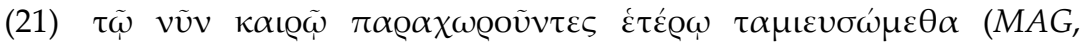
p. 153.20-21).

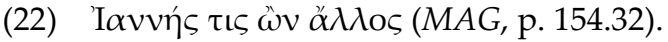

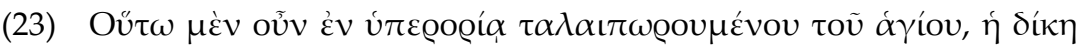

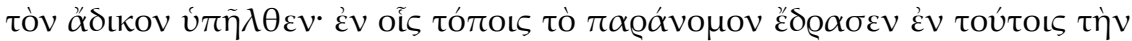

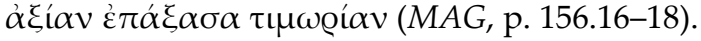

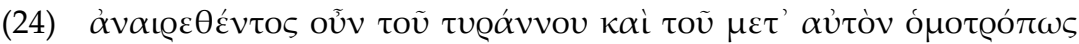

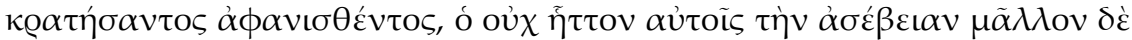

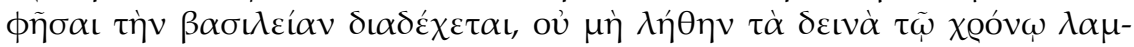


All these evasions, as well as the fact that the Vita does not speak a word about the death of Theophilos or about the Restoration of Icons, suggest that Sabas wrote his hagiographic work during the lifetime of Theophilos when one could receive harsh punishment for too bold diatribes against the Iconoclastic Emperors or their spiritual leaders like John the Grammarian. ${ }^{25}$

Given all the above, the Vita of St. Makarios of Pelekete can be dated to 836-842.

\section{SUMMARY}

An analysis of the sources shows that the death of St. Makarios of Pelekete took place after 835, and his Vita should be dated to 836-842.

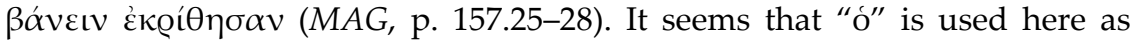
indication "this one," "the current one."

(25) For example, Sts. Theodore and Theophanes the Branded were punished by the Emperor Theophilos in 836, among other things, for the fact that they "rejoiced the death of Leo" the Armenian and wrote some satirical verses about it (see T. A. SÉNINA (moniale Kassia), "La confession de Theophane et Theodore les Graptoi: remarques et précisions," Scr, 4 (2008), pp. 266, 288-290). Incidentally, prior to this, the Brothers were in exile on the same island of Aphusia, where Makarios was exiled during the reign of Theophilos, and where the author of his Vita was the abbot after the death of the saint. Possibly, Sabas' reference to the "horrors" which will "not be condemned to oblivion with time" meant the punishment inflicted on the Branded Brothers. 